\title{
Refinements of Antagonism in Discourse Theory for European Studies
}

\author{
Thomas HOERBER
}

Discourse Theory has in recent years gained importance in Political Science and more specialised sub-disciplines such as International Relations ${ }^{1}$ and European Studies. This article will try to show why Discourse Theory has developed a growing appeal in summarising its strengths. Particularly for European Studies, Discourse Theory holds potential when it analyses "the role of language in the construction of the EU", demonstrating that "the various attempts to capture the union's nature are not mere descriptions of an unknown polity, but take part in the construction of the polity itself'. ${ }^{2}$ Discourse Theory, for one, exposes that 'Europe' itself is a contested concept and not a neutral reality, ${ }^{3}$ a contested concept in the process of the definition of which Discourse Theory may prove its usefulness.

\section{Methodology}

The main research question of this essay is therefore, whether Discourse Theory, as coined by Ernesto Laclau and Chantal Mouffe has academic merit; and whether Discourse Theory adds anything to our understanding of European integration history.

The first part of this paper will present the main elements of current Discourse Theory, i.e. the analytical tools of Antagonism, Hegemony and Nodal Points. ${ }^{4}$ The second part will suggest refinements to the most underdeveloped analytical element of Discourse Theory, i.e. Antagonism. By using post-war European integration as an example, the essay will propose three refinements of Antagonism in order to bring the analytical potential to the fore. In the conclusion, the question as to the added value will be answered, firstly, in terms of improvements within Discourse Theory through the proposed refinements; secondly, in comparison to other theories, emphasising, in particular, the analytical potential of Antagonism. This will be done on the basis of empirical findings taken from an extensive study of parliamentary debates

1. See B. BUZAN, O. WAEVER, J. de WILDE, Security : A New Framework for Analysis, Lynne Rienner, Boulder, 1998.

2. T. DIEZ, Speaking 'Europe': The Politics of Integration Discourse, in: JEPP, special issue 1999, p.599; for the formative power of language see M. FOUCAULT, Histoire de la sexualite, Gallimard, Paris, 1984, p.127.

3. T. DIEZ, Speaking 'Europe' ..., op.cit., p.602.

4. E. LACLAU, C. MOUFFE, Hegemony and Socialist Strategy, Verso, London, 1985; see also C. MOUFFE, The Return of the Political, London, Verso, 1993 and E. LACLAU, The making of political identity, Verso, London, 1994. 
in France, Germany and Britain in the 1950s, ${ }^{5}$ which very much give that "general sense of a discursive community". 6 The period of the 1950 s is particularly well suited for that analysis, because European integration was still strongly contested in the societal and political arenas. The empirical part is based on historical archival work on parliamentary debates on European integration ideas in France, Germany and Britain.

\section{Antagonism}

One core theme of Discourse Theory is the constitutive role of Antagonism in social life. Laclau and Mouffe argue that Antagonism performs a constitutive role for a society, by defining itself against an outside 'other'. ${ }^{7}$ The use of Antagonism as an analytical tool enables the evaluation of current EU policy. The 'other' can be the past, as frequently happened in European integration. For example, post-war Germany defined itself in opposition to its Nazi-past; the same is true for the $4^{\text {th }}$ Republic in France in its definition against Vichy France and its Nazi-collaborators; and even in Britain the Appeasement policy of the Chamberlain Government became a formidable cornerstone of what should never happen again. The 'other' may also be another state, for example, the Antagonism between the US and the USSR during the Cold War. One structural problem with Laclau and Mouffe's concept of Antagonism is that it often describes inner-societal affairs. Particularly David Howarth's later refinement of social Antagonism bears this hallmark of inner-societal struggle. ${ }^{8}$ However, these aspects of Antagonism bear some striking similarities with the other core concept of Discourse Theory, i.e. Hegemony which will be explained in the next section.

\section{Hegemony}

Laclau and Mouffe define their second key concept, Hegemony, in Hegemony and Socialist strategy. ${ }^{9}$ While Antagonism covers the external dimension, Hegemony deals with internal contest, i.e. politics. Both concepts are linked in that they identify

5. T.C. HOERBER, European Integration Ideas in France, Germany and Britain in the 1950s, VS Verlag, Wiesbaden, 2006.

6. J. ROGERS, From 'Civilian Power' to 'Global Power': Explicating the European Union's 'Grand Strategy' Through the Articulation of Discourse Theory, in: JCMS, 4(2009), p.839.

7. C. MOUFFE, The Return ..., op.cit., p.2.

8. D. HOWARTH (ed.), Discourse Theory and Political Analysis: Identities, Hegemonies and Social Change, MUP, Manchester, 2000; D. HOWARTH, J. TORFING (eds), Discourse Theory in European Politics, Palgrave, Basingstoke, 2005, p.15.

9. E. LACLAU, C. MOUFFE, op.cit. 
the political 'contest'. Hegemonization is the term applied to the political process by which the dominance of political ideas is established. It represents a struggle for the dominant norms and values within society, but one which is facilitated by discussion and political debate from which those shared values may emerge. Further struggle may occur within the political debate and subsequently the norms of the discourse may be confirmed or changed. The process of hegemonization recognises the conditions in society which allow for change yet at the same time provides the context for stability. ${ }^{10} \mathrm{~A}$ good example of this inner-societal contest in the post-war period is the struggle of what Europe was and should be in the future. It could become a loose and weak collection of states under the auspices of the Council of Europe, or a deeply integrated (supranational) Union of Member States with real power over them, as in the European Coal and Steel Community. This example also shows the blurring of the internal/external distinction between Hegemony and Antagonism. The discourse about the sense and the direction of European integration after World War II was becoming an inner-European discourse while it was led, at the same time, between different nation states.

\section{Nodal points}

The third theme which Laclau and Mouffe identify is that of creation of 'Floating Signifiers' or 'Nodal Points' in the discourse. ${ }^{11}$ These lead to the creation of centres of political focus in a discursive field acting as an ordering mechanism in the discourse. ${ }^{12}$ The more Hegemony a political group has over a Nodal Point the more powerful it is in politics. ${ }^{13}$ Hegemonizing a Nodal Point also allows the dominant political group to modify societal core values, such as behavioural patterns, for example the term 'Europe' lacks meaning, therefore political forces compete to modify the content of this word, which in turn embodies the political process and also facilitates it. An example of the hegemonisation of the term 'Europe' would be liberal Europe versus social Europe as a policy, or Europe versus the EU as the overall polity, or EFTA versus the EEC in the politics of the 1950s.

10. T. DIEZ, Speaking 'Europe' ..., op.cit., p.603. See also D. HOWARTH, J. TORFING (eds), op.cit., p.15.

11. D. HOWARTH, J. TORFING (eds), op.cit., pp.323-324; J. ROGERS, op.cit., pp.838-839.

12. T. DIEZ, Die EU lesen: diskursive Knotenpunkte in der britischen Europadebatte, Leske + Budrich, Opladen, 1999, chapter 2 and T. DIEZ, Speaking 'Europe' ..., op.cit., p. 611.

13. E. LACLAU, Emancipation(s), Verso, London, 1996, p.43. 


\section{Refinements of Discourse Theory}

"Discourse theory is still under theoretical refinement and elaboration". ${ }^{14}$ In the following section, this article will try to provide some refinements which may be of particular use to scholars of European studies and History, because in order to turn Antagonism into a helpful analytical tool for European Studies and History, it may have to become a bit more concrete. The refinements will be divided into three additional concepts of Antagonism, i.e. Political Antagonism, Historical Antagonism and Antagonism to military involvement.

\section{Political Antagonism}

On the most general level, 'Political Antagonism' accounts for the opposition of the West to the East. In a negative sense such Political Antagonism can be seen in discourses of securitization.

"[W]e observe the existence of a conflict when an actor constructs his or her identity or interests in such a way that these cannot be made compatible with the identity or interests of another actor". ${ }^{15}$

In the Cold War context, this was the Antagonism of the Western bloc formed by the United States of America and Western Europe to the Eastern bloc, i.e. the Soviet Union, Eastern Europe and to a lesser extent China and other communist countries of South-East Asia. ${ }^{16}$ The antagonistic discourse underpinning the two blocks is brilliantly described by Paul Chilton (1996). Antagonism in the version of Laclau and Mouffe explains the formation and continuous opposition of the two blocs in that the existence of the other made the still existing differences within the blocs acceptable to its members and strengthened the unity within each bloc. ${ }^{17}$ It supported the communal identity among the members of each side and once fully developed it worked as a pillar of 'Eastern' and 'Western' integrity. Therefore, Western identity was based

14. J. ROGERS, op.cit., p.835. For important additions to Discourse Theory and the discursive construction of Europe, see B. TONRA, Constructing the Common Foreign and Security Policy: the utility of a cognitive approach, in: Journal of Common Market Studies, 4(2003); B. TONRA, T. CHRISTIANSEN (eds), Rethinking European Union Foreign Policy, MUP, Manchester, 2004; O. WAEVER, European Integration and Security: Analysing French and German Discourses on State, Nation and Europe, in: D. HOWARTH, J. TORFING (eds), op.cit., pp.33-67; C. MEYER, Convergence Towards a European Strategic Culture? A constructivist framework for explaining changing norms, in: European Journal of International Relations, 4(2005), pp.523-549; P. CORNISH, G. EDWARDS, Beyond the EU/NATO Dichotomy: the beginnings of a European strategic culture, in: International Affairs, 3(2001), pp.587-603.

15. T. DIEZ, S. STETTER, M. ALBERT, The European Union and Border Conflicts : The Transformative Power of Integration, in: International Organizations, Summer 2006, pp.565-566.

16. J. TORFING, New theories of discourse: Laclau, Mouffe and Zizek, Blackwell, Oxford, 1999, pp.125-126; J. ROGERS, op.cit., p.837.

17. O. WAEVER, op.cit., p.38. 
on, or at least supported by, the opposition to the USSR. Opposition to the Soviet system in general and allegiance to Western liberal principles accounts partly for integration into the relatively loose Western systems of cooperation, e.g. the Western European Union (WEU) and the North Atlantic Treaty Organisation (NATO). ${ }^{18}$

Political Antagonism as a general commitment to Western values and institutions can be found in France, Germany and Britain in the 1950s, and it can, indeed, be seen as a uniting bond between the three states. ${ }^{19}$ An example would be the shared Antagonism of all three states to the Soviet threat and expansionism in their respective rearmament programmes, e.g. just before the Korean War in 1950, under the auspices of Western defence organisations as NATO. Indeed, this fear of Soviet expansionism, and hence Antagonism, was one reason for the change of mind in France and Britain leading to the conviction that West Germany must be brought into the Western bloc and into the Western defence systems as a full member, despite considerable misgivings about German rearmament, in particular in France.

This logic applied to the post-Cold War period provides another interesting conclusion. During the Cold War, the certainty of absolute destruction was sufficiently solid to build an identity on. This argument can be found in Winston Churchill's "foundations of mutual terror". ${ }^{20}$ A victory against the outside enemy was a victory and one could be sure of survival because of the threat of finality of nuclear war. With the end of the Cold War those foundations were destroyed. That means security of survival was lost; and insufficient Antagonism was left to stabilise identity. This could be seen as the reason for a crisis of identity in the West, after the Cold War.

\section{Historical Antagonism}

An even stronger form of Antagonism can be seen in 'Historical Antagonism', i.e. the Antagonism against one's own past or rather the opposition to previous regimes, such as in Nazi Germany, or preceding generations, such as against Vichy collaborators in France. One could also call it the 'Never Again Effect', meaning that politically or historically disastrous mistakes attributed to previous generations should be avoided at all costs. In discourse speak this phenomenon is sometimes called 'dislocation' and consequent 'articulation' of opposition against the dislocating event or

18. B. HEUSER, NATO, Britain, France and the FRG - Nuclear Strategies and Forces for Europe, 1949-2000, Macmillan, London, 1998.

19. O. WAEVER, op.cit., pp.44 and 47; T.C. HOERBER, op.cit., pp.76-87 for France, pp.171-180 for Germany and pp.256-266 for Britain.

20. The official Report of the House of Commons, Hansard 1950, vol.473, c.198. 
the reason for it. ${ }^{21} \mathrm{~A}$ good example of this general rejection of past practice can be seen in the post-1945 reaction to inter-war politics (1919-1939), the consequences of which were perceived as being the outbreak of World War II, e.g. Neville Chamberlain's Appeasement policy in Britain, Raymond Poincaré's policy of isolating Germany, and German non-collaboration with the post World War I Allies; later on extreme nationalism and the Holocaust, might serve as examples. ${ }^{22}$ As a consequence of such Historical Antagonism, a credible alternative is sought, i.e. Franco-German reconciliation became a defining factor for the identity of both nations in the postwar period and indeed for European integration as a whole. ${ }^{23}$ Historical Antagonism, therefore, creates identity from the opposition towards a political method or against a whole political system of the past and it accounts for the dismay felt by the postwar generation at the repercussion of such policies on their lives. This Antagonism also accounts for today's commitment to Western liberal values based on the opposition of past totalitarian regimes. ${ }^{24}$

In the French context this can explain the rejection of the quasi-Fascist Vichy regime. ${ }^{25}$ Comparatively strong popular Antagonism to surviving traces or structures of the earlier period, such as civil servants or industrialists who remained in their positions, was amply reflected during the French Fourth Republic (1946-1958) in the strong electoral performances of the French Communists, who could make some claim to have run the resistance movement during the Vichy regime almost singlehandedly. On the other hand, the Gaullists, on the right of the political spectrum, saw the humiliating defeat in 1940 and the subsequent Vichy collaboration with the Nazi occupiers as a result of the faulty constitutional arrangements of the Third Republic: the weaknesses of government were attributed to the almost unlimited powers of parliament and the exploitation of these weaknesses by the political parties ('le régime des partis') for their own ends. The situation was not very different in the Fourth Republic. Hence, Historical Antagonism can also explain the uncompromising op-

21. See E. LACLAU, New Reflections on the Revolution of Our Time, Verso, London, 1990, p.39; D. HOWARTH, Hegemony, Political Subjectivity, and Radical Democracy, in: S. CRITCHLEY, O. MARCHART (eds.), Laclau: A critical Reader, Routledge, Oxford, 2004, pp.263-264; J. ROGERS, op.cit., p.837.

22. H. LARSEN, Discourse Analysis in the study of European foreign policy, in: B. TONRA, T. CHRISTIANSEN (eds), op.cit., p.74; D. DINER, Memory and Restitution: World War II as a Foundation Event in a Uniting Europe, in: D. DINER, G. WUNBERG (eds), Restitution and Memory. Material Restoration in Europe, Berghahn Books, New York, 2007, pp.9-19; A. ASSMANN, Europe: A Community of Memory?, in: Bulletin of the German Historical Institute (40), Paris, 2007; L. PROBST, Founding Myths in Europe and the Role of the Holocaust, in: New German Critique, autumn(2003), p.54; T. JUDT, Postwar - A History of Europe since 1945, Penguin, New York, 2005, p.804; O. WAEVER, op.cit., pp.47-48, J. ROGERS, op.cit., p.841.

23. O. WAEVER, op.cit., pp. 34-55; J. ROGERS, op.cit., pp.844-845; R. COOPER, ESDP Goals and Ambitions, US-EU PolMil Conference, Brussels, 2005, available at: http://consilium, p.4.

24. H. LARSEN, op.cit., p.73.

25. See R.O. PAXTON, Vichy France - Old Guard and New Order 1940-1944, Columbia University Press, New York, 2001. 
position of the right and far right, in particular the Gaullists, to the Fourth Republic as a whole. ${ }^{26}$

In the German context, Historical Antagonism offers a clear explanation of the rejection, in post-war Germany, of the Nazi regime.

"A break between generations was expressed in mutual distrust. Young people felt their parents had betrayed them by bringing the Nazi dictatorship and its subsequent holocaust upon them; the older generation retaliated by denouncing the self-pity of a generation that seemed to accept the Nazi slogan, 'After us, the flood'. This distrust accentuated the young people's aversion to politics and their suspicion of yet another program of re-education". 27

Because of the strong emphasis the Third Reich and the generation which supported it had placed on extreme nationalism, Historical Antagonism can explain why the ideal of the nation state was weakened in the German discourse, as Kurt Schumacher the leader of the opposition and the SPD put most strikingly. "Now, perhaps more than all other peoples, we distrust the idea of the nation state as the ultimate wisdom". ${ }^{28}$ More generally, the cry for freedom which rang throughout Europe in 1968 can be seen as a revolt against the past rigidity of the political and social system on the part of a post-war generation claiming its own right to shape the societies it lived in, not least on the basis of opposition to the previous generation's way of life, i.e. Historical Antagonism.

In both the French and the German cases, the consequence of Historical Antagonism can be seen in the development of the European idea, the core values of which must be seen in anti-war and anti-isolationist attitudes..$^{29}$ These are clearly reflected in the European integration effort represented by the European Coal and Steel Community (ECSC), the abortive European Defence Community (EDC), the European Economic Community (EEC) and Euratom. Importantly, the first serious steps towards integration - the ECSC and the EDC - were designed to make future warfare between the participants not just unthinkable but materially impossible, to speak with Robert Schuman's words. ${ }^{30}$

The British case is different from those of France and Germany, where the rationale of Historical Antagonism refers to a critical rejection of the disastrous behaviour

26. P. SAMUEL, Michel Debré: L'architecte du Général, Arnaud Franel Eds, Suresnes, 1999.

27. F. Roy WILLIS, France, Germany, and the New Europe, 1945-1967, OUP, Oxford, 1968, p.44.

28. W. ALBRECHT (ed.), Kurt Schumacher, Reden-Schriften-Korrespondenzen, Dietz, Berlin, 1985, p.750, German original: „Wir Deutschen sind, vielleicht mehr als alle anderen Völker, jetzt geneigt, im Nationalstaat nicht der Weisheit letzter Schluss zu sehen". Schumacher's keynote speech: "Social democracy in its struggle for Germany and Europe“, 22.05.1950.

29. See P. GERBET, La Construction de l'Europe, $3^{\text {rd }}$ ed., Imp. Nationale, Paris, 1999. See also, J. MONNET, Mémoires, Fayard, Paris, 1976; F. DUCHÊNE, Jean Monnet - The first statesman of interdependence, Norton, New York, 1994.

30. See Schuman Declaration, 1950, in: A.G. HARRYVAN, J. VAN DER HARST (eds), Documents on the European Union, Macmillan Press, London, 1997, pp.61-63; R.T. GRIFFITHS, Europe's First Constitution The European Political Community, 1952-1954, Federal Trust, London, 2000; E. FURSDON, The European Defence Community - A History, Macmillan, London, 1980. 
and political (in)action of the previous generation and remains to some extent related to the experience of military defeat (1940 for France and 1945 for Germany). The Appeasement policy could be considered an example, but it remained rather an episode in history which was remedied by the succeeding Churchill government. Britain escaped defeat on home territory, invasion and occupation which France and Germany experienced. Consequently, Historical Antagonism against the previous political regime remained relatively weaker in Britain. There was definitely an anti-war sentiment early on, but the victory in the war served to confirm in the British political system legitimacy and public credibility which were tarnished in both France and Germany. In turn, this major difference may be seen as one reason for Britain's reluctance to join either the ECSC or the EDC. ${ }^{31}$

\section{Antagonism to Military Involvement}

The last suggested refinement of the concept of Antagonism and arguably its strongest form is opposition to military involvement. To some extent it is a particular form of Historical Antagonism, but it is important as it explains, in particular, Germany's reluctance to develop a military potential and its rather passive role in all military organisations. This kind of Antagonism can be seen as the post-war reaction to historical German (especially Prussian) militarism. It explains the repercussions of the war experience of the German people and the consequent German reluctance to participate in any post-war military venture. Particularly on the opposition benches mainly the Social-Democrats until 1966 - but also in the broader peace movement, the resistance to German rearmament is based on this form of Antagonism. ${ }^{32}$ Later, Ole Waever argues that Germany's refusal to go into Iraq was based on Chancellor Gerhard Schroeder's reestablishment of German national interest in the Berlin Republic. ${ }^{33}$ However, this refusal also ties in well with the more long-standing German Antagonism towards military involvement and it connects nicely to the point outlined under 'Historical Antagonism' in so far as France also refused and both together stood against the involvement in the Iraq war - one might argue in the best maintenance of the European core value of peace - see the concept of the European Community as

31. K. HARRIS, Attlee, Weidenfeld \& Nicolson, London, 1995, pp.506-507; R. JENKINS, Churchill, Macmillan, London, 2001; P. ADDISON, Churchill - the unexpected hero, Oxford University Press, Oxford, 2005; J.W. YOUNG (ed.), The Foreign Policy of Churchill's Peacetime Administration 1951-1955, Leicester UP, Leicester, 1988.

32. B. BOUVIER, Erich Ollenhauer (1901-1963), in: T. OPPELLAND (ed.) Deutsche Politiker, 1949-1969, vols.1,2, Primus, Darmstadt, 1999; P. MERSEBURGER, Der schwierige Deutsche Kurt Schumacher, DVA, Stuttgart, 1995; P. MERSEBURGER, Kurt Schumacher (1895-1952), in: T. OPPELLAND (ed.), op.cit.

33. O. WAEVER, op.cit., p.57. 
a 'civilian power'. ${ }^{34}$ For the EC, this Antagonism toward military involvement can also be seen as the reason for the notoriously weak European Security and Defence Policy, consequently the late arrival of the Common Foreign and Security Policy, and certainly the lacking capabilities to act militarily, even when crisis broke in its own backyard such as on the Balkans in the 1990s. ${ }^{35}$

Back in the 1950s, France faced a similar situation of a lost war and a bitter and humiliating war experience. However, Antagonism against military involvement is, in the French case, offset by the colonial and world-wide responsibilities which further necessitated military engagement for France, notably in Indochina from 1946 and Algeria until 1962. Hence, French opposition to military involvement was not hampered to the same extent by past experience, although there was considerable resistance among the French people to France's military involvement in Indochina and Algeria, a resistance which is sometimes seen as contribution to their defeat in both wars. ${ }^{36}$ However, in the German case Antagonism against military involvement must also be seen as a reflection of the German abdication of its position as both a world power and as a great military power after World War II.

In the German case, Antagonism against military involvement resulted not only in abstention from military action, as outlined above, but also in a firm commitment to non-military integration, such as the ECSC, or the EEC. Germany's leading role and enthusiastic participation in the EEC can be explained, at least in part, by the unmistakably non-military nature of this institution, which was particularly important for the support of the SPD for the European Economic Community in 1957 in contrast to their rejection of the European Coal and Steel Community in 1950 which they saw as an economic tool in the Cold War.

It is indeed this positive side of Antagonism to military involvement which can be found in France and Britain, too. For these two, the military defeats in Indochina and Algeria, in the French case, and particularly Suez, ${ }^{37}$ in the British case, triggered a comprehensive strategic reappraisal and a weakening of the colonial and imperialist mindset. In Britain, it was followed by the 1957 Defence Review, with its emphases on missiles and nuclear defence. In both countries, the military defeats lent strength to the political camp opposed to military action and also to a stronger commitment to European integration and even a swing towards Europe, first for France after its

34. F. DUCHÊNE, Europe's role in World Peace, in: R. MAYNE (ed.), Europe Tomorrow: Sixteen European Look Ahead, Fontana, London, 1972; F. DUCHÊNE, The European Community and the Uncertainties of Interdependence, in: M. KOHNSTAMM, W. HAGER (eds), A Nation Writ Large? Foreign Policy Problems before the European Community, Macmillan, London, 1973; H. LARSEN, op.cit., p.71; J. ROGERS, op.cit., p.841.

35. B. SIMMS, Unfinest Hour: Britain and the Destruction of Bosnia, Penguin, London, 2001; H. LARSEN, op.cit., p.74; J. ROGERS, op.cit., pp.841-842.

36. J. TALBOTT, The War without a Name - France in Algeria 1954-1962, Faber \& Faber, Boston, 1980, p.7.

37. See C. de GAULlE, Mémoires d'espoir, Plon, Paris, 1970; C.G. COGAN, Charles de Gaulle A Brief Biography with Documents, St. Martin's Press, Boston, 1996; C. WILLIAMS, The Last Great Frenchman, Abacus, London, 1996; E. ROUSSEL, Charles de Gaulle, Nrf Gallimard, Paris, 2002. 
European partners had refrained from an outright critical stance against France during the Suez crisis, one consequence of which was the full commitment to the Messina process, the re-launch of the European integration process. ${ }^{38} \mathrm{~A}$ few years later the outcome of Britain's necessary reappraisal of its place in relation to Europe and the problem of European integration was manifested in this country's applications for full membership of the EEC.

Both the anti-war and the pro-integration trends can be attributed to a search for new strategic options and, not least, additional resources for the national treasuries drained by the wars. The European alternative fitted both bills and was a reasonable option for France and Britain, even for Prime Minister Anthony Eden - generally reported as 'cool' towards Europe - who came to see a re-orientation towards Europe as a serious option only a few days before he resigned after the disastrous Suez campaign. ${ }^{39}$ The fact that his successor Harold Macmillan gave priority to the special relationship with America does not invalidate this observation, as evidenced by his own swing towards Europe in the application for full EEC membership in 1961. Therefore, it can reasonably be argued that from then on European integration was seen as a possible means of providing Britain with strategic and even financial support too advantageous now to be ignored. In that sense this particular Antagonism concept provides another explanation for the growing and almost undisputed success of the European integration process from the mid- to end-1950s.

One further argument which features Antagonism against military involvement is provided by the historical detail that the Suez crisis provided additional ammunition to the section of French parliamentarians who were opposed to military engagement. The link between the failed EDC (August, 1954) and the Suez disaster of 1956 was made mainly by the most fervent Europeanists of the Mouvement Républicain Populaire (MRP). The main argument was that had the EDC been in place in 1956, European troops would never have been sent to Egypt. ${ }^{40}$ In that sense it is perhaps not an Antagonism to military engagement per se, as in the German case, but rather the reasoning that sensible 'European' military structures might have prevented the Suez venture altogether, sparing France another military defeat and considerable damage to its prestige. However, much more than the anti-war argument, the pro-integration, pro-European argument shows its strength in France's foreign policy in the second half of the $1950 \mathrm{~s} .{ }^{41}$ By that time, European economic integration had become one of France's main economic pillars and ensured the abundant provision of re-

38. M. VAÏSSE, La Grandeur - Politique étrangère du general de Gaulle 1958-1969, Fayard, Paris, 1998; D. DUTTON, Anthony Eden, A Life and Reputation, Arnold, London, 1997; D. GOWLAND, A. TURNER, Reluctant Europeans - Britain and European Integration, 1945-1998, Longman, London, 2000.

39. D. DUTTON, op.cit., pp.310 and 446; E. HEATH, The Course of My Life: My Autobiography, Hodder \& Stoughton, London, 1998, p.178; G.R. WLKES, British Attitudes to the European Economic Community, 1956-63, unpublished PhD thesis, Cambridge, 2002, pp.33 and 41; T.C. HOERBER, op.cit., pp.293-398.

40. T.C. HOERBER, op.cit., pp.65-75.

41. J. DOISE, M. VAÏSSE, Politique étrangère de la France: Diplomatie et outil militaire 1871-1991, Imprimerie nationale, Paris, 1992. 
sources - notably coal and steel under the ECSC - of which there had previously been shortages. The French initiative at Messina - in the Euratom project driven by Jean Monnet - had the clear goal of extending these mutually beneficial cooperative arrangements to wider areas of the economy. The Common Agricultural Policy (CAP) is only the most publicised instance of the direct economic benefits France reaped from the economic integration process, so that it is not surprising that European economic cooperation as a whole had become a key French policy underpinning its general economic policy and helping to ensure its economic viability. It had manifestly provided a successful economic alternative to the dependence of metropolitan France on imports not only from the US, but more importantly from the crumbling colonial empire. Moreover, European integration provided a political alternative to the Empire, which also resulted in a more relaxed approach to independence movements in overseas holdings. The handling of the independence of Tunisia by the government of Pierre Mendès-France is a good example. ${ }^{42}$

Hence, the essence of the Antagonism to military involvement can be seen as the consequence of lost military engagements in all three countries and in an increase in the motivation to search for alternative policy options and a stronger emphasis on peaceful settlement of conflicts. In this, the guiding ideals of European integration peace and prosperity - find their reflection. The beneficial effects of such policies have been felt in France, Germany and Britain, as well. Antagonism against military involvement can therefore be seen as part and parcel of EU core values. An analysis of the consequences was not the purpose of this historical analysis, but the EU's preference for soft power, its weak military structures and its strong civilian expertise can be seen as obvious consequences.

\section{Conclusion}

As shown for France, Germany and Britain, Discourse Theory and in particular the refined versions of Antagonism have an analytical potential which can enhance our understanding of political phenomena such as the European integration process and national politics. In that sense, Discourse Theory adds an important theoretical approach. In contrast to other integration theories, Discourse Theory puts the emphasis on speeches, debates or discourse in the wider sense. It is, therefore, particularly useful for primary research which depends on such sources, such as parliamentary debates. Just like Discourse Theory, these sources are especially concerned with the genesis and the development of ideas, which makes Discourse Theory very useful for analysing the idealistic roots of the European integration process, as shown above. In comparison, the emphasis is not on the power struggle between states as in realist

42. J. LACOUTURE, Pierre Mendès-France, Seuil, Paris, 1981, pp.266-282. 
theory, ${ }^{43}$ or on the internal bargaining process of liberal theories, resulting in the formation of national preferences. ${ }^{44}$ Liberal intergovernmentalism - in the rational choice tradition-seems to combine realist and liberal theoretical strands successfully, adding the intriguing element of vested interests of national elites in the European integration process, insofar as European integration provides an improved bargaining position for the national elites against their political opponents at home. However, like the previous theoretical approaches, liberal intergovernmentalism fails to provide the explanation of idealistic motivation behind European integration. Intergovernmentalism, most extensively applied to European Studies by Alan Milward, also dismisses motivations based on the European ideal in favour of concrete economic profit for the sake of rescuing the nation state. ${ }^{45}$ Although he admits the importance of the political dimension for his economic analysis, he neglects the political, in order to bring out the economic argument. ${ }^{46}$ Discourse Theory, in contrast, puts the emphasis on precisely these political motivations, accounting for the initial political spark and the underlying political will facilitating the admittedly predominantly economic early European integration process, e.g. in the European Coal and Steel Community. The political forces cannot be left out of the analysis without distorting the picture of the European integration process. Lastly, in neo-functionalism, clearly, a technocratic nature of integration was envisaged. ${ }^{47}$ Concepts such as 'spill over' - where politics follows economics - illustrate that very well. ${ }^{48}$ Mainly Charles de Gaulle's political intervention, however, curtailed the integration process, using national interest as the main reason. His successful blockade - empty chair crisis - cast considerable doubt upon the neo-functionalist logic of almost automatic, continuous and nearly unstoppable integration. ${ }^{49}$ In neo-functionalism, too, European idealism as a political force is largely curtailed under the veil of technocratic progress in European integration. George Wilkes aptly puts this criticism that such previous approaches have

43. See H.J. MORGENTHAU, Politics Among Nations: The Struggle for Power and Peace, New York, Knopf, 1985; K. WALTZ, Theory of international Politics, McGraw, New York, 1979.

44. A. MORAVCSIK, Negotiating the Single European Act', in: R.O. KEOHANE, S. HOFFMANN (eds.), The New European Community: Decision Making and Institutional Change, Boulder, Westview Press, 1991; A. MORAVCSIK, The Choice for Europe: social purpose and state power from Messina to Maastricht, UCL Press, London, 1998, chapter 1; A. WIENER, T. DIEZ, European Integration Theory, OUP, Oxford, 2004, p.8.

45. See A.S. MILWARD, The Reconstruction of Western Europe, 1945-51, Methuen, London, 1984; A.S. MILWARD, The European Rescue of the Nation State, Routledge, London, 2000; H. WALLACE, Politics and Policy in the European Union: the Challenge of Governance, in: H. WALLACE, W. WALLACE (eds), Policy-Making in the European Community, John Wiley \& Sons, Chichester, 1996.

46. M. BURGESS, Federalism and European Union: the Building of Europe, 1950-2000, Routledge, London, 2000, pp.34, 38, 55-56, 66 and 93; see also W. DIEBOLD Jr., The Schuman Plan: a Study in Economic Cooperation, 1950-1959, F.A. Praeger, New York, 1959, p.664.

47. See D. BELL, The End of Ideology: On the Exhaustion of Political Ideas in the Fifties, Free Press, New York, 1962.

48. B. ROSAMUND, Theories of European Integration, Palgrave, Houndmills, 2000, p.60.

49. See P.C. SCHMITTTER, A Revised Theory of European Integration, in: L.N. LINDBERG, S.A. SCHEINGOLD (eds), Regional Integration: Theory and Research, Harvard University Press, Cambridge, MA, 1971. 
stressed economic motivations too strongly and that idealistic reasons have been neglected..$^{50}$

Discourse Theory has potential in adding a stronger analytical emphasis on idealism than other theoretical approaches. It has been shown to be especially applicable to analysis of the early European integration process, because its inbuilt idealist characteristic coincides markedly with the underlying motivations of the European integration process, which have been neglected in other theoretical approaches.

Within Discourse Theory, Antagonism is the least developed analytical concept, in need of a clearer distinction from Hegemony. On the basis of the suggested refinements of Antagonism in this article, Antagonism could be more clearly defined as a concept that explains underlying long-term motivations that lead to external action or the foreign policy position of a political unit, i.e. a state or the EU. Antagonism would thus be the bridge between domestic and foreign policy issues by the use of domestic policy positions for the definition of foreign policy, as shown in the examples of 'Historical Antagonism' and 'Antagonism against military engagement'.

50. G.R. WILKES, op.cit., p.4. 


\section{Denkart Europa.}

\section{Schriften zur Europäischen Politik, Wirtschaft und Kultur}

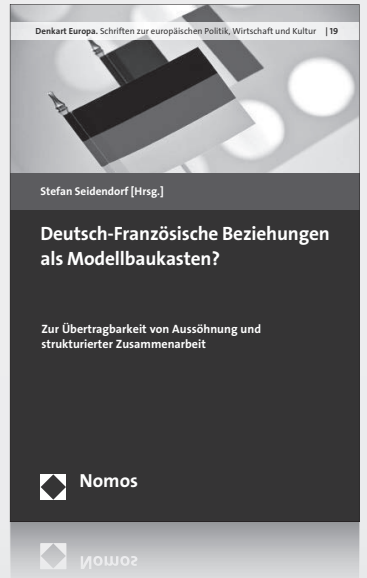

Deutsch-Französische Beziehungen als Modellbaukasten? Zur Übertragbarkeit von Aussöhnung und strukturierter Zusammenarbeit Herausgegeben von Stefan Seidendorf 2012, Band 19, 218 S., brosch., 29, - € ISBN 978-3-8329-7467-1

www.nomos-shop.de/14638

Kann das Modell der deutsch-französischen Beziehungen als zwischenstaatliche Friedensordnung auf andere Staaten übertragen werden? Basierend auf den Elementen „zivilgesellschaftliche Aussöhnung“ und „institutionalisierte Zusammenarbeit“ untersucht der Band Möglichkeiten, deutschfranzösische Nachkriegserfahrungen zu verallgemeinern.

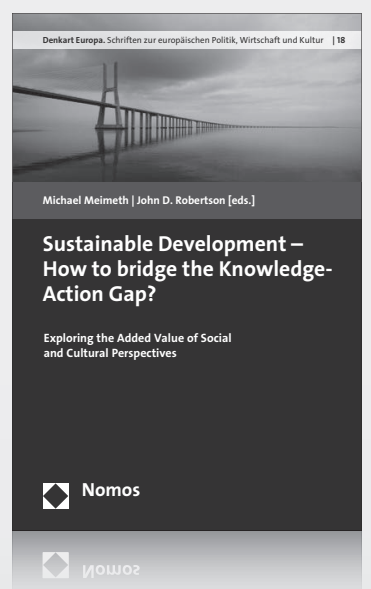

Sustainable Development - How to bridge the Knowledge-Action Gap?

Exploring the added value of social and cultural perspective Herausgegeben von Michael Meimeth und John D. Robertson 2012, Band 18, 185 S., brosch., 25,-€ ISBN 978-3-8329-7299-8 www.nomos-shop.de/14452

Nachhaltige Entwicklung ist seit mehr als zwei Dekaden auf der politischen Agenda und hat sich zu einem populären und bedeutenden Konzept entwickelt. Der Band untersucht die Besonderheiten kultureller und sozialer Herausforderungen für eine kohärente und effektive Strategie Nachhaltiger Entwicklung in den USA und Europa. 